\title{
PAX9 wt Allele
}

National Cancer Institute

\section{Source}

National Cancer Institute. PAX9 wt Allele. NCI Thesaurus. Code C140001.

Human PAX9 wild-type allele is located in the vicinity of $14 q 13.3$ and is approximately 22

$\mathrm{kb}$ in length. This allele, which encodes paired box protein Pax-9, plays a role in fetal

development. Mutation of the gene is associated with selective tooth agenesis type 3

and cleft palate. 